\title{
Deoxyribonucleic Acid Relationship Between Spiroplasma citri and the Corn Stunt Spiroplasma
}

\author{
H. RAHIMIAN AND D. J. GUMPF \\ Department of Plant Pathology, University of California, Riverside, California 92521
}

\begin{abstract}
Spiroplasma citri and the corn stunt spiroplasma were compared by deoxyribonucleic acid reassociation. Homologies among Spiroplasma citri strains ranged from 93 to $100 \%$, but between Spiroplasma citri and the corn stunt spiroplasma, the homology was about $68 \%$. It is therefore concluded that the corn stunt spiroplasma and Spiroplasma citri may belong to the same species but to separate subspecies or biovars.
\end{abstract}

Spiroplasma citri, the causal agent of citrus stubborn disease, was first isolated and grown on artificial media in $1971(12,26)$. Since its isolation, it has been the subject of extensive studies, including those that led to its description as a species (27) and classification in the family Spiroplasmataceae in the order Mycoplasmatales (29). After considerable effort, the corn stunt spiroplasma (CSS) was also grown on cellfree media $(5,36)$. Since then, although there have many comparative studies, mostly serological, between these two organisms $(5,10,20,33-$ 36 ), the status of the CSS within the genus Spiroplasma is not well resolved. Complicating the issue even further is an increasing number of reports on the isolation of new spiroplasmas from different sources (8).

Based mainly on the results of growth inhibition tests, Davis et al. (10) differentiated four spiroplasma serogroups. Results from serological deformation, microprecipitin, and ring-interface tests also supported this grouping. Williamson et al. (35) came to similar conclusions. Although it is not indicated at present to assign specific status to members of this grouping other than Spiroplasma citri, Davis et al. (10) suggested that the other serogroups represent different Spiroplasma species. These serological studies $(10,34)$ suggest that, whereas some new spiroplasmas are completely distinct, the CSS may represent a serological subgroup showing partial relationship to $S$. citri. Padhi et al. (20) compared the electrophoretic patterns of the cell proteins of several spiroplasmas and concluded that the CSS belongs to a unique species. However, unless protein electrophoretic patterns are totally different or virtually the same, such results are inconclusive because there is no established line of demarcation to differentiate spiroplasmas into species or subspecies. Furthermore, there is no precedent for species delineation solely on this basis (14). Eventually, twodimensional gel electrophoresis of cell proteins (18) may be more valuable than one-dimensional electrophoresis in comparative studies of spiroplasmas. For example, in contrast to the conclu- sions of Padhi et al. (20), considerable similarities between the CSS and Spiroplasma citri were demonstrated by two-dimensional gel electrophoresis (18). Although Bové and Saillard (4) compared electrophoretic patterns of restriction endonuclease fragments of several Spiroplasma citri isolates and the CSS, the technique was most useful in differentiating Spiroplasma isolates.

Nucleic acid homologies have been used extensively in bacterial taxonomy $(15,17,28)$ including, to a limited extent, comparative studies of some mycoplasmas $(3,19,21-23,30)$ and Spiroplasma citri isolates $(25,32)$.

The present study was undertaken to examine the value of deoxyribonucleic acid (DNA) homology as a taxonomic tool for differentiating the CSS from Spiroplasma citri.

\section{MATERIALS AND METHODS}

Organisms and media. The organisms used were: Spiroplasma citri strains C189 (=ATCC 27665), Morocco (=ATCC 27556), Cir3B (I.-M. Lee, University of California, Riverside, Calif.), and M1744 (E. C. Calavan, University of California, Riverside, Calif.); CSS 1747 (=ATCC 29051; via R. E. Davis, U.S. Department of Agriculture, Beltsville, Md.); Acholeplasma laidlawii (=ATCC 14089); Mycoplasma hominis (=ATCC 23114); Escherichia coli L127 (J. V. Leary, University of California, Riverside, Calif.); and Salmonella typhi. murium TA98 (W. L. Belser, University of California, Riverside, Calif.). Spiroplasma citri isolates were grown in SMC medium (27) supplemented with $10 \%$ fetal calf serum (GIBCO Laboratories, Grand Island, N.Y.). The CSS was grown in a medium described by Stevens et al. (Proc. Am. Phytopathol. Soc., Abstr. no. S-40, p. 229-230, 1977). Acholeplasma laidlawii and Mycoplasma hominis strains were grown according to the method described by Robertson et al. (24). Nutrient broth (Difco Laboratories) plus glucose was used for growing the Escherichia coli and Salmonella ty. phimurium strains.

DNA extraction. Cells were harvested by centrifugation, and the DNA was extracted according to the method of Marmur (16), with two phenol extractions and isopropanol precipitation after ribonuclease treatment.

Preparation of labeled DNA. ${ }^{3} \mathrm{H}$-labeled DNA was prepared by growing the organisms in their re- 
spective medium containing $1 \mu \mathrm{Ci}$ of $\left[{ }^{3} \mathrm{H}\right]$ thymidine (specific activity, $23 \mathrm{Ci} / \mathrm{mmol}$; New England Nuclear Corp., Boston, Mass.) per ml. The cells were harvested at the early stationary phase, and the DNA (specific activity, 25,000 to $60,000 \mathrm{cpm} / \mu \mathrm{g}$ ) was purified as described above.

Solutions of DNA in $0.1 \times \mathrm{SSC}$ (SSC is $0.15 \mathrm{M}$ $\mathrm{NaCl}, 0.015 \mathrm{M}$ sodium citrate, $\mathrm{pH} 7$ ) were stored at $4^{\circ} \mathrm{C}$ over a few drops of chloroform.

Agarose gel electrophoresis of DNA. Purified DNA from all organisms was subjected to electrophoresis in $0.7 \%$ agarose (Sigma Chemical Co.) dissolved in $\mathrm{F}$ buffer (1). Electrophoresis was performed in a vertical slab gel ( 15 by 15 by $0.15 \mathrm{~cm}$ ) apparatus (31) for 1 to $4 \mathrm{~h}$ at $90 \mathrm{~V}$. The gels were stained in $0.5 \mu \mathrm{g}$ of ethidium bromide per $\mathrm{ml}$ for $10 \mathrm{~min}$. Plasmid DNA isolated from Escherichia coli and Salmonella typhimurium by the method of Currier and Nester (7) were used as references.

Polyacrylamide gel electrophoresis of cell proteins. Spiroplasmas were harvested by centrifugation at $12,000 \times g$ for $30 \mathrm{~min}$ and washed three times in $0.25 \mathrm{M}$ phosphate-buffered saline $(0.25 \mathrm{M} \mathrm{NaCl}$ in 0.01 $\mathrm{M}$ prosphate buffer, $\mathrm{pH} 7$ ). The washed cells were dispersed and solubilized according to the method of Amar et al. (2). Electrophoresis was carried out in discontinuous slab gels according to the procedure of Studier (31), with $10 \%$ resolving and $6 \%$ stacking gels.

DNA duplex formation. Native DNA $(30 \mu \mathrm{g} / \mathrm{ml}$ in $0.1 \times \mathrm{SSC}$ ) was denatured by boiling for $10 \mathrm{~min}$ and rapid chilling. The concentration of DNA was adjusted to $10 \mu \mathrm{g} / \mathrm{ml}$ in $6 \times \mathrm{SSC}$ by the addition of concentrated SSC. Three-milliliter amounts of these DNA solutions were passed by slow suction through 25-mm filters (type HAWP, 0.45- $\mu \mathrm{m}$ pore size; Millipore Corp., Bedford, Mass.) that had previously been soaked in $6 \times$ SSC and washed with $20 \mathrm{ml}$ of the same solution. DNA retention was estimated at 90 to $97 \%$ by monitoring the optical density, at. $260 \mathrm{~nm}$, of the filtrates. The filters were then washed with $25 \mathrm{ml}$ of $6 \times$ SSC and dried at room temperature overnight and then in a vacuum oven at $80^{\circ} \mathrm{C}$ for $2 \mathrm{~h}$ (13). Labeled DNA (20 $\mu \mathrm{g} / \mathrm{ml}$ in $0.1 \times \mathrm{SSC}$ ) was sheared in a Biosonik II (Bronwill) sonicator to an average molecular weight of $2 \times 10^{5}$. Loaded filters were preincubated in the preincubation mixture of Denhardt (11). The filters were removed, blotted, and transferred to vials containing $2 \mu \mathrm{g}$ of sheared, heat-denatured, labeled DNA in $1 \mathrm{ml}$ of $2 \times \mathrm{SSC}$. The vials were incubated at $56^{\circ} \mathrm{C}$ for $30 \mathrm{~h}$ (predetermined). The vials were then cooled, and the filters were washed in place with two changes of $2 \times \mathrm{SSC}$ and then with $20 \mathrm{ml}$ of the same buffer on each side. The filters were dried and counted in toluene-based scintillation fluid in a scintillation counter.

\section{RESULTS}

Agarose gel electrophoresis of DNA. All DNA preparations used in hybridization studies showed a single chromosomal DNA band on agar gel. One of the Spiroplasma citri isolates (isolate Cir3B) subjected to the plasmid DNA extraction procedure of Currier and Nester (7) showed only a faint chromosomal DNA band, whereas the reference bacterial isolates showed a similar band in addition to their characteristic plasmid bands. Therefore, the DNA preparations were considered to be devoid of any detectable extrachromosomal DNA. Such DNAs have been shown to exist in some Spiroplasma citri isolates (4).

Electrophoretic pattern of cell proteins. The cell-protein patterns of Spiroplasma citri isolates and the CSS are compared in Fig. 1. The patterns were identical for all Spiroplasma citri isolates. Spiroplasma citri and the CSS, although sharing a number of common bands, differed in others.

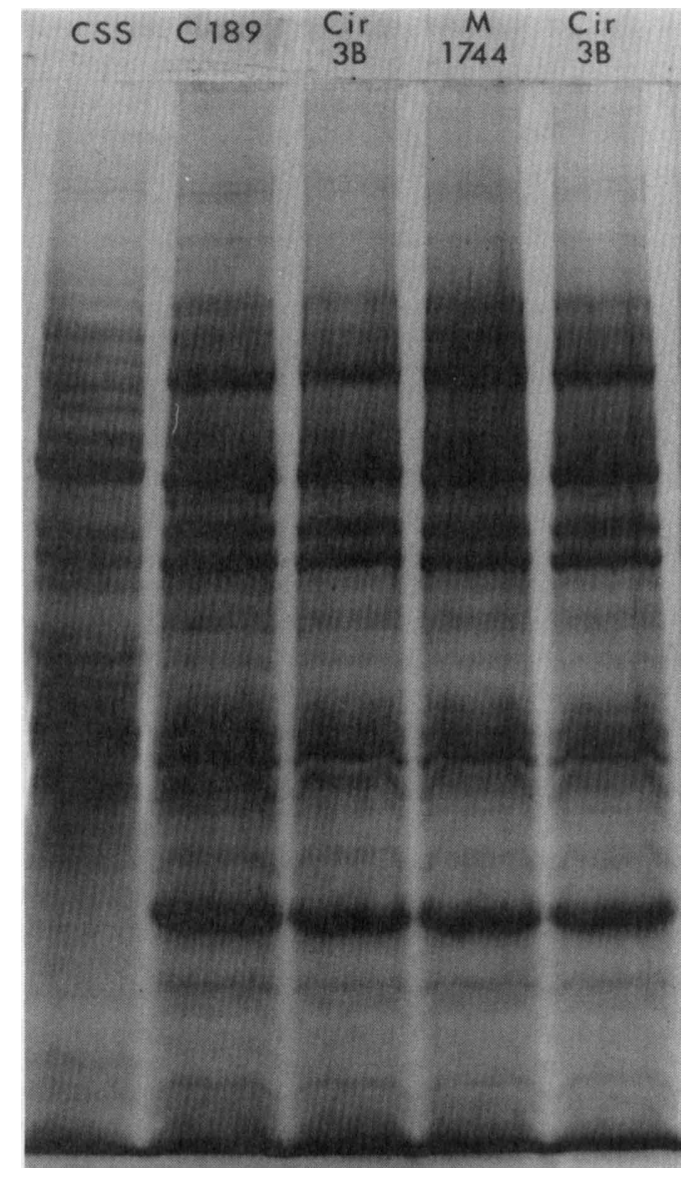

FIG. 1. Electrophoretic patterns of Spiroplasma proteins. Washed Spiroplasma cells were dispersed and solubilized in sodium dodecyl sulfate buffer and electrophoresed on discontinuous slab gels. CSS, Proteins, from corn stunt spiroplasma; C 189, proteins from a California isolate of Spiroplasma citri iso. lated from stubborn citrus tree; Cir $3 B$, proteins from a California isolate of Spiroplasma citri isolated from a leafhopper vector, Circulifer tenellus; $M$ 1744, proteins from a California strain of Spiroplasma citri isolated from stubborn citrus tree. 
TABLE 1. DNA homologies of selected spiroplasmas

\begin{tabular}{|c|c|c|c|c|}
\hline \multirow{3}{*}{ Unlabeled DNA } & \multicolumn{4}{|c|}{ \% Homology ${ }^{n}$ to: } \\
\hline & \multicolumn{2}{|c|}{ Spiroplasma citri $\mathrm{C} 189$} & \multirow{2}{*}{$\begin{array}{c}\text { Spiroplasma citri } \\
\text { Cir3B } \\
\text { (expt 1) }\end{array}$} & \multirow{2}{*}{$\begin{array}{c}\operatorname{CSS} 1747 \\
\text { (expt 1) }\end{array}$} \\
\hline & Expt 1 & Expt 2 & & \\
\hline Spiroplasma citri C189 & $100[20,760]^{b}(4)^{a}$ & $100[31,240](4)$ & $95.05 \pm 2.12(4)$ & $69.45 \pm 5.45(4)$ \\
\hline S. citri Cir3B & $95.15 \pm 0.65(2)$ & $102.28 \pm 3.92(5)$ & $100[14,140](3)$ & $67.36 \pm 1.75(3)$ \\
\hline S. citri Morocco & $102.50 \pm 0.50(2)$ & & & \\
\hline S. citri M1744 & $97.50 \pm 2.50(2)$ & & & \\
\hline $\operatorname{CSS} I 747$ & $67.70 \pm 0.35$ & $66.65 \pm 3.13(4)$ & $68.90 \pm 5.20(3)$ & $100[25,730](5)$ \\
\hline Mycoplasma hominis & $8.10 \pm 0.28(4)$ & $6.39 \pm 0.39(2)$ & $8.40 \pm 0.10(2)$ & 7.60 (1) \\
\hline Acholeplasma laidlawii & $2.16 \pm 0.09(3)$ & & & $2.12 \pm 0.2(3)$ \\
\hline Calf thymus & 0.20 & & & \\
\hline Blank & 0.20 & 0.10 & 0.40 & 0.40 \\
\hline
\end{tabular}

${ }^{a}$ Relative to the homologous reaction, in which the binding is arbitrarily set at $100 \%$.

${ }^{b}$ Absolute binding values are given in brackets.

' Numbers in parentheses give the number of determinations.

DNA base sequence relationship among Spiroplasma isolates. The results of DNA annealing tests are presented in Table 1. All Spiroplasma citri isolates tested showed over 95\% similarity to the C189 strain. The CSS showed $67 \pm 3 \%$ homology to C189 and $69 \pm 5 \%$ homology to Cir3B. In the reciprocal experiment, in which labeled CSS DNA was used as reference, the degrees of homology of C189 and Cir3B to the CSS were $69 \pm 5$ and $67 \pm 2 \%$, respectively. Acholesplasma laidlawii and $M y$ coplasma hominis showed $2 \%$ and 6 to $8 \%$ homologies, respectively, with the spiroplasmas.

\section{DISCUSSION}

In a comparative serological study of spiroplasmas, Spiroplasma citri and the CSS were placed in two different subgroups (namely, subgroups A and C) of group I, with other spiroplasmas occupying three other groups (10). The relatedness of these two spiroplasmas has also been established with binding of the DNA of partially purified CSS to labeled Spiroplasma citri DNA (9). Padhi et al. (20) considered the differences between Spiroplasma citri and the CSS sufficient to place the latter in a separate species.

The polyacrylamide gel electrophoresis patterns of the cell proteins of all Spiroplasma citri isolates tested were identical, but they differed from that of the CSS (Fig. 1). The difference was partial, however, in that some protein bands were common to both. In two-dimensional protein electrophoretic studies of spiroplasmas, Mouches et al. (18) found a few common proteins and a significant number of homologous proteins in Spiroplasma citri and the CSS. From the protein maps, they concluded that the CSS shows definite relatedness to Spiroplasma citri, but suckling mouse cataract spiroplasma probably deserves a different species designation.

In DNA reassociation studies, all Spiro- plasma citri strains examined showed a high degree of homology under optimum conditions. Saglio et al. (25) and Townsend et al. (32) also found a high level of relatedness among Spiroplasma citri isolates. The degree of DNA homology between the CSS and Spiroplasma citri isolates $\mathrm{C} 189$ and Cir3B is between 63 and $74 \%$ (average, 68\%); in the reciprocal experiment a similar value (64 to $75 \%$ [average, $68 \%$ ]) was obtained. If a taxonomic scheme were to be devised on the basis of nucleic acid homology as applied to bacteria (15), the CSS, which apparently has more than $60 \%$ homology with Spiroplasma citri, may belong to the same species or biovar. However, using a similar procedure, Christiansen et al. (6) found $30 \%$ homology between the DNA of Spiroplasma citri and that of the CSS and a homology of $5 \%$ or less between these spiroplasmas and the suckling mouse cataract agent. A final decision on the proper assignment of the CSS to a separate species or to a subspecies or biovar of Spiroplasma citri should await comparative analysis of more isolates of the CSS by serology, gel electrophoresis, and DNA reassociation. It may also be helpful to determine the change in melting temperatures of CSS-Spiroplasma citri heteroduplexes (15).

\section{REPRINT REQUESTS}

Address reprint requests to: Dr. D. J. Gumpf, Department of Plant Pathology, University of California, Riverside, CA 92521.

\section{LITERATURE CITED}

1. Aaij, C., and P. Borst. 1972. The gel electrophoresis of DNA. Biochim. Biophys. Acta 269: 192-200.

2. Amar, A., S. Rottem, I. Kahane, and S. Razin. 1976. Characterization of the mycoplasma membrane proteins. VI. Composition and disposition of proteins in membranes from aging Mycoplasma hominis culture. Biochim. Biophys. Acta 426:258-270.

3. Askaa, G., and H. Ernø. 1976. Elevation of Mycoplasma agalactiae subsp. bovis to species rank: Mycoplasma bovis (Hale et al.) comb. nov. Int. J. Syst. Bacteriol. 26: 323-325. 
4. Bove, J. M., and C. Saillard. 1979. Cell biology of spiroplasmas, p. 85-153. In R. F. Whitcomb and J. G. Tully (ed.), The mycoplasmas, vol. 3, Plant and insect mycoplasmas. Academic Press, Inc., New York.

5. Chen, T. A., and C. H. Liao. 1975. Corn stunt spiroplasma: isolation, cultivation, and proof of pathogenicity. Science 188: 1015-1017.

6. Christiansen, C., G. Askaa, E. A. Freundt, and R. F. Whitcomb. 1979. Nucleic acid hybridization experiments with Spiroplasma citri and the corn stunt and suckling mouse cataract spiroplasmas. Curr. Microbiol. 2:323-326.

7. Currier, T. C., and E. W. Nester. 1976. Isolation of covalently closed circular DNA of high molecular weight from bacteria. Anal. Biochem. 76:431-442.

8. Davis, R. E. 1979. Spiroplasmas: newly recognized arthropod-borne pathogens, p. 451-484. In K. Maramorosch and K. F. Harris (ed.), Leafhopper vectors and plant disease agents. Academic Press, Ind., New York.

9. Davis, R. E., G. Dupont, P. Saglio, B. Roy, J. C. Vignault, and J. M. Bové. 1974. Spiroplasmas: studies on the microorganism associated with corn shunt disease. Coll. Inst. Natl. Sante Rech. Med. 33:187-194.

10. Davis, R. E., I.-M. Lee, and L. K. Basciano. 1979. Spiroplasmas: serological grouping of strains associated with plants and insects. Can. J. Microbiol. 25:861-866.

11. Denhardt, D. T. 1966. A membrane-filter technique for the detection of complementary DNA. Biochem. Biophys. Res. Commun. 23:641-646.

12. Fudl-Allah, A. E.-S. A., E. C. Calavan, and E. C. K Igwegbe. 1972. Culture of a mycoplasma-like organism associated with stubborn disease of citrus. Phytopathology 62:729-731.

13. Gillespie, D., and S. Spiegelman. 1965. A quantitative assay for DNA-RNA hybrids with DNA immobilized on a membrane. J. Mol. Biol. 12:829-849.

14. International Committee on Systematic Bacteriology, Subcommittee on Taxonomy of Mollicutes. 1979. Proposal of minimal standards for descriptions of new species of the class Mollicutes. Int. J. Syst. Bacteriol. 29:172-180.

15. Johnson, J. L. 1973. Use of nucleic acid homologies in the taxonomy of anaerobic bacteria. Int. J. Syst. Bacteriol. 23:308-315.

16. Marmur, J. 1961. A procedure for the isolation of deoxyribonucleic acid from microorganisms. J. Mol. Biol. 3 . 208-218.

17. Moore, R. L. 1974. Nucleic acid reassociation as a guide to genetic relatedness among bacteria. Curr. Top. Microbiol. Immunol. 64:105-128.

18. Mouches, C., J. C. Vignault, J. G. Tully, R. F. Whitcomb, and J. M. Bové. 1979. Characterization of spiroplasmas by one- and two-dimensional protein analysis on polyacrylamide slab gels. Curr. Microbiol. 2:69-74.

19. Neimark, H. C. 1971. Division of mycoplasmas into subgroups. J. Gen. Microbiol. 63:249-263.

20. Padhi, S. B., A. H. MeIntosh, and K. Maramorosch. 1977. Characterization and identification of spiroplasmas by polyacrylamide gel electrophoresis. Phytopathol. Z. 90:268-272.

21. Peterson, A. M., and M. E. Pollock. 1969. Deoxyribonucleic acid homology and relative genome size in $\boldsymbol{M y}$. coplasma. J. Bacteriol. 99:639-644.

22. Reich, P. R., N. L. Somerson, C. J. Hybner, R. M. Chanock, and S. M. Weissman. 1966. Genetic differentiation by nucleic acid homology. I. Relationships among Mycoplasma species of man. J. Bacteriol. 92: 302-310.

23. Reich, P. R., N. L. Somerson, J. A. Rose, and S. M. Weissman. 1966. Genetic relatedness among mycoplasmas as determined by nucleic acid homology. J. Bacteriol. 91:153-160.

24. Robertson, J., M. Gomersall, and P. Gill. 1975. Myco. plasma hominis: growth, reproduction and isolation of small viable cells. J. Bacteriol. 124:1007-1018.

25. Saglio, P., R. E. Davis, R. Dalibart, G. Dupont, and J. M. Bové. 1974. Spiroplasma citri: 1'espece type des spiroplasmes. Coll. Inst. Natl. Sante Rech. Med. 33:2734.

26. Saglio, P., D. Laflèche, C. Bonissol, and J. M. Bové. 1971. Isolement, culture et observation an microscope electronique des structures de type mycoplasme associees a' la maladie due Stubborn de agrumes et leur comparison avec les structures observees dans le cas de la maladie du Greening des agrumes. Physiol. Veg. 9: 569-582.

27. Saglio, P., M. L'hospital, D. Laflèche, G. Dupont, J. M. Bové, J. G. Tully, and E. A. Freundt. 1973. Spiroplasma citri gen. and sp. n.: a mycoplasma-like organism associated with "Stubborn" disease of citrus. Int. J. Syst. Bacteriol. 23:191-204.

28. Sanderson, K. E. 1976. Genetic relatedness in the family Enterobacteriaceae. Annu. Rev. Microbiol. 30:327-349.

29. Skripal, I. G. 1974. On the improvement of taxonomy of the class Mollicutes and establishment in the order Mycoplasmatales of the new family Spiroplasmataceae. Fam. Nova. Mikrobiol. Zh. Kiev 36:462-467.

30. Somerson, N. L., P. R. Reich, B. E. Walls, R. M. Chanoek, and S. M. Weissman. 1966. Genetic differentiation by nucleic acid homology. II. Genotypic variations within two Mycoplasma species. J. Bacteriol. 92: 311-317.

31. Studier, F. W. 1973. Analysis of bacteriophage $T_{7}$ early RNAs and proteins on siab gels. J. Mol. Biol. 79:237248 .

32. Towsend, R., P. G. Markham, K. A. Plaskitt, and M. J. Daniels. 1977. Isolation and characterization of a non-helical strain of Spiroplasma citri. J. Gen. Microbiol. 100:15-21.

33. Tully, J. G., R. F. Whitcomb, J. M. Bové, and P. Saglio. 1973. Plant mycoplasmas: serological relation between agents associated with citrus stubborn and corn shunt diseases. Science 182:827-829.

34. Tully, J., G., R. F. Whitcomb, H. F. Clark, and D. L. Williamson. 1977. Pathogenic mycoplasmas: cultivation and vertebrate pathogenicity of a new spiroplasma. Science 195:892-894.

35. Williamson, D. L., J. G. Tully, and R. F. Whitcomb. 1979. Serological relationships of spiroplasmas as shown by combined deformation and metabolism inhibition tests. Int. J. Syst. Bacteriol. 29:345-351.

36. Williamson, D. L., and R. F. Whitcomb. 1975. Plant mycoplasmas: a cultivable spiroplasma causes corn shunt disease. Science 188:1018-1020 